\title{
Collectivist Logic in Comparative Genocide Studies and in the Battles for Memory
}

\begin{abstract}
Aвstract: The article aims to present the mechanisms of collectivist logic as it functions in three areas: (1) in the historical comparative analysis of genocides - the basic method of genocide studies; (2) in the activities of the organizations of victims and survivors, as well as in actions undertaken by animal rights activists; (3) in nationalist discourses and in the politics of memory. Collectivist logic is a set of operations that address human communities - groups of individuals linked together by significant social bonds and interests, and perceived as culturally distinctive as the subject of history. As a result of the application of such logic, we may think about collective guilt and collective merit. The article discusses the advantages and disadvantages of historical comparative analysis as an essential methodological tool of genocide studies. The argument further focuses upon the use of the symbolic capital attributed to the term "genocide" in studies involving analyses comparing other crimes - as well as the industrial exploitation of animals to genocides. Finally, the author describes the relationship between the state policy of memory, nationalist discourses, and the academic integrity of genocide scholars.
\end{abstract}

KEYWORDS: historical comparative analysis, genocides, genocide studies, politics of memory

The term "collectivist logic," as I use it in this article, refers to a set of operations that address human communities - groups of individuals linked together by significant social bonds and interests, and perceived as culturally distinctive as the subject of history. In such a context, individual strategies, activities, and achievements are treated as manifestations of the group's activities and the emphasis falls on the importance of the dominant social practices while minority practices are marginalized. It is collectivist logic that allows us to think about collective guilt or collective merit, or to speak of "nations as perpetrators of crimes" and of "victim nations." It is such logic that encourages one to explain group actions by reference to dominant macro-social attitudes and factors. 
Furthermore, collectivist logic is the foundation of discourses leading to the replication of imagined communities, such as nations. At the same time, its manifestations may be found in scientific and scholarly discourses, which, as one would expect, should be immune to the "substantialization" of the described groups. Too often, however, the descriptions of genocide progress from stating statistical regularities, or the importance of macro-social factors, to treating states, nations, or ethnic groups as monoliths sharing common social awareness. The diversity within the described communities is thereby neglected, and so are the often inconsistent, and sometimes contradictory, actions of both perpetrators and victims. Equally disregarded is then the importance of the micro-social factors and the uniqueness of the local context.

The premises underlying such operations may vary. Errors of this type may occur as a consequence of mental shortcuts or economics of the academic narrative, but they may also result from the adoption of particular social theories, from the implementation of a particular politics of memory, or from a bias towards - or against - a given social category. The main objective of this article is to describe how collectivist logic operates within the field of comparative historical studies, which is the basic method of genocide studies, and how it relates to public battles about the interpretation of the past (including politics of memory developed in particular countries or pursued internationally).

\section{Comparative Research in Genocide Studies}

Comparative research is indispensable for the development of genocide studies. Its practice, however, often arouses controversy, especially among the Shoah specialists emphasizing the "uniqueness" of the genocide of the Jews (the positions adopted by scholars significantly vary; for instance, Yehuda Bauer writes that the Shoah is "an extreme form of genocide," which makes it unprecedented ${ }^{1}$ ).

Of course, each historical event is "unique" because at a given point of the time-space continuum a particular scenario played out, and not any other. Historians carefully examine past events, attempting to discover new aspects of the processes described. And yet, even though the literature on the subject is enormous, the historians of the Holocaust still face a serious challenge. Oftentimes, however, this challenge does not consist in examining new archives, but in the courage to ask questions that - until recently - would have been considered

${ }^{1}$ Y. BAuER: Rethinking the Holocaust. New Haven 2002, p. 50. Cf. D. B. MacDonald: Balkan Holocausts? Serbian and Croatian Victim Centred Propaganda and the War in Yugoslavia. Manchester 2002, pp. 39-62. 
inappropriate as violating time-honored social taboos. This is the case with war rape and sexual exploitation, which, for decades, remained hidden behind the veil of popular morality. To exemplify the problem, it has only been in 2018 that the first Polish monograph comprehensively describing the fates of the forced sex workers in the occupied territories of Poland - including the functioning of brothels in Nazi concentration camps (the so-called Puffs) - was published. ${ }^{2}$

Social sciences, however, attempt to identify regularities and diagnose universal processes that historically lead to events such as revolutions, wars, or genocide. The objective of such research is not only to explain (or understand) the past phenomena: it is also to estimate the probability of their recurrence. In this case, the explanatory potential of the theory is measured by its power to predict the future. This aspect of sociological research is also of enormous practical importance. Alerting the public opinion to the risk of the recurrence of genocide and fostering heightened awareness of such a possibility may lead to the prevention of acts of mass extermination in the future, even if such an intervention does not allow us to determine to what extent our predictions would have proved correct.

The most important method employed in genocide research involves historical comparative case studies. It has a long tradition in sociological research (suffice it to mention such scholars as Max Weber, Marc Bloch, Reinhard Bendix, or Barrington Moore Jr.). Theda Skocpol distinguished three types of logic governing comparative studies in sociology. ${ }^{3}$ The first type, comparative history as the parallel demonstration of theory, aims to demonstrate that a given theory (or hypothesis) retains its explanatory potential even if it is applied to a number of dissimilar cases. A good example of sociological research following this logic is the work The Political Systems of Empires by Shmuel Noah Eisenstadt. The second type, comparative history as the contrast of contexts, consists in the juxtaposition of cases, which are then studied from the point of view of their uniqueness and analyzed in the light of a variety of local factors determining the course of social processes under research. In studies carried out with the use of this method, local variability is ignored as contextual, while in research following the method focusing on divergence it is the differences that are presented as of key importance to a given social phenomenon. An example of a work based on such comparative logic is Islam Observed by Clifford Geertz. Finally, the third type, comparative history as macro-causal analysis, derives theoretical generalizations from gradual, systematic comparative analyses of particular cases - and, as such, it is a typically inductive approach. An example of a study employing this method is Social Origins of Dictatorship and Democracy: Lord and Peasant

2 J. Ostrowsкa: Przemilczane. Seksualna praca przymusowa w czasie II wojny światowej. Warszawa 2018.

3 Т. SкосроL: Social Revolutions in the Modern World. Cambridge 1994, pp. 72-92. 
in the Making of the Modern World by Barrington Moore Jr. The above notwithstanding, it must be noted that, in practice, authors of comparative studies often combine a variety of the types of logic.

Each of these models has its advantages and disadvantages. Comparative history as the parallel demonstration of theory often boils down to the tedious repetition of theoretical arguments. In its logic, case studies only serve to illustrate the theory; the analyses to which particular cases are subjected contribute nothing new to the model proposed at the onset. In turn, comparative history as the contrast of contexts is its opposite: it presents individual cases emphasizing their rich variety and their uniqueness without bending them to fit the theoretical template. At the same time, with this approach, researchers do not focus on theories, hypotheses, or problems to explain. Finally, comparative history as macro-causal analysis, which model is the closest to Skocpol's position, allows for inductive theory building, but generalizations are limited to the cases analyzed. Applying these generalizations to other regions of the world, especially ones shaped by a different history and molded in a different culture, may yield dubious effects. ${ }^{4}$

Conducting research on genocides, however, does not suffice. It is also necessary to explore cases in which factors generally recognized as sources of the mobilization for genocide were indeed present yet, ultimately, no acts of extermination took place. Such a strategy may be constructed on the basis of either of two methods: the method of compliance and the method of difference. Both refer to John Stuart Mill's canons. In the case of the method of compliance, the procedure relies upon the following logic: if a certain observed phenomenon (e.g. a war) is regularly ensued by another phenomenon (e.g. social anomy), even though other phenomena taken into account as significant for the study do not occur, then this initial phenomenon should be considered to be the causative factor, while all other phenomena, observed locally (such as the type of the political system in place), ought to be understood as circumstantial variables accompanying the global process. In turn, the method of difference is based on the reinforcement of observations previously made: if in the case under study the effect (anomy) never occurred, although all other circumstances - with the exception of the causative factor - did occur, it means that the absent phenomenon (the war) is the condition determining the occurrence of genocide. Of course, in practice, whenever Multiple Factor Analysis (MFA) is adopted as the fundament of the study, the procedure itself becomes complicated - and thereby research into the reasons why, in certain cases, genocide did not occur has not been taken up too often. ${ }^{5}$

${ }^{4}$ Ibidem, pp. 86-90.

${ }^{5}$ See, for instance, my study into why the genocide of the German population never happened: L.M. Nijakowski: Rozkosz zemsty. Socjologia historyczna mobilizacji ludobójczej. Warszawa 2013. 
Comparative studies always concern selected cases. At the same time, the characteristics of the non-probability (purposive) sampling affect the results. The researcher must make an informed decision as to which mass crimes to exclude from the sample - and, of course, be aware of the fact that each such choice will arouse (more or less) vehement emotions on the part of the commentators. And yet, the decision is crucial: the inclusion of too many crimes, which - in the sociological sense - would be qualified as non-genocidal (e.g. acts of bloody pacification of rebellious provinces, war massacres, or cases of political terror), may lead to one's inability to properly describe the paths of genocidal mobilization. On the other hand, too small a sample may render one's findings excessively dependent on particular conditions, in which genocides under study were perpetrated. Researchers' decisions in this regard are too often judged from a moral perspective ("denying the victims their dignity") or from a politically motivated standpoint ("disregarding our political interest").

Comparative studies in sociology presuppose some forms of the standardization of cases. Countries and regions - albeit differing in terms of their unique cultural conditioning, individual path dependence, particular institutional resources, etc. - are analyzed with reference to a coherent, uniform conceptual frame. Such a standardization becomes visible with particular clarity when we carry out statistical analyses requiring the formalization of various aspects of social life. Among others, studies carried out by Barbara Harff or Ted Robert Gurr ${ }^{6}$ exemplify the above procedure.

From the point of view of scholars specializing in regional research, such measures lead to inevitable simplifications. This, however, is the price to be paid if one wishes to build a general model or an explanatory theory. The above notwithstanding, such simplifications do generate problems of substantial importance to other disciplines - such as literary or cultural comparative studies - and the sociological standardization itself often becomes an object of their criticism. The well-known postcolonial scholar, Gayatri Chakravorty Spivak, went so far as to proclaim "the death of the discipline," demanding that emphasis be paid to the diversity in the contemporary world and that multiculturality be cultivated. ${ }^{7}$

While designating objects for comparison, we naturally become indebted to theoreticians, whose work guides our research. If we are in favor of the systems theory or lean towards some other model of social emergence, we can compare social wholes without reservations. But if we choose to follow theories based on methodological individualism, then we must reckon with the possible consequences of the fact that our comparisons may be based on much weaker

${ }^{6}$ B. HarfF: "No Lessons Learned from the Holocaust? Assessing Risks of Genocide and Political Mass Murder since 1955." American Political Science Review 2003, vol. 97, no. 1, pp. 57-73; B. HARFF, T.R. GuRR: "Systematic Early Warning of Humanitarian Emergencies." Journal of Peace Research 1998, vol. 35, no. 5, pp. 551-579.

${ }^{7}$ G.Ch. SpIVAK: Death of a Discipline. New York 2003. 
theoretical foundations. We are fine if we are aware of the implications of the said theoretical choices - choices closely related to particular social ontologies we consciously accept. Yet, the situation is much worse when we resort to the use of "colloquial theoretical knowledge," that is, when we duplicate stock classifications and commonplace theses, imprinted in our minds since our undergraduate years, without properly realizing the importance of the multitude of concurrent anthropological, epistemological, and ontological assumptions determining our actions. This, alas, is often the case with historians, who, reconstructing facts about the past, regard the efforts made by historical sociologists with an air of superiority.

When comparing phenomena of a scale as formidable as that of genocide, we must always perform a careful selection of both the sources of information and particular aspects of the reality to be described, as it seems obvious that even a case study is not capable of addressing the uniqueness of a given region in its entirety. Furthermore, while conducting comparative studies, we should simplify the described social reality to an even greater extent: these are the indisputable costs of the choice of a comparative method. Such a choice involves numerous pitfalls, including the dangers associated with the application of collectivist logic to our object of study. For example, in the case of the Rwandan genocide in 1994, it is often said that the Hutu murdered the Tutsi. In fact, among the victims of the civil war there were also the Rwandan Pygmies (Twa) and the moderate Hutu who either were seen as political opponents of the Hutu-led government or chose to help the Tutsi. Yet, in clarifying this, we recognize that it was the national identity that was essential for the actors of the Rwandan tragedy. In many cases, however, it was the group membership that gave individuals an "administrative stigma," associated directly with an entry concerning ethnicity in their ID cards. During the war, the identity issues became even more complicated in mixed marriages. In each region, the behavior of the Hutu depended on the long-term path dependence, which becomes especially clear if one keeps in mind that it was the Hutu refugees who had previously fled the Tutsi crimes (e.g. in Burundi) who proved to be particularly zealous as killers. Likewise, the behaviors of neighbors living in the same location, yet representing different ethnicities, would vary. This allows one to observe that an individual's micro-spatial environment was a factor of significance, which may have helped predicting the diversity of forms of individual participation in the acts of genocide. ${ }^{8}$ Of course, one could provide many more examples supporting the claim that the reality of the inter-group conflict was far more complex than the image usually presented in narratives dedicated to the genocide in Rwanda (including academic texts).

${ }^{8}$ O.S. McDoom: "Who Killed in Rwanda's Genocide? Micro-space, Social Influence and Individual Participation in Intergroup Violence.” Journal of Peace Research 2013, vol. 50, no. 4, pp. 453-467. 
Our choice to leave social diversification aside is tantamount to making necessary simplifications for the sake of the efficiency of our comparative study. Arguably, it is a legitimate procedure, on condition that we overtly write about our choices, explaining the principles we abide by while reducing the complexity of the described phenomena to the level deemed needed. Yet, it is only too often that collectivist logic, activated in such situations, triggers the use of strategies frequently employed in discriminating discourses, such as the strategies of "genericization" (referring to whole groups of people generically - e.g. "Germans") or "assimilation" (referring to social actors as groups). ${ }^{9}$

When comparing Germans, Turks, and Hutu as perpetrators of total genocides in the 20th century, we ignore the complexity of circumstantial factors that made people - who, in the light of personality or intelligence tests, were perfectly normal - kill others with their own hands or support genocidal projects, while holding on to their projection of themselves as individuals of unquestionable morality, acting for the good of their families and their national (or ethnic) communities. ${ }^{10}$ And it is not only that such strategies simply result in the leaving out of the Righteous, who would put their own lives on the line to save the lives of Jews, Roma, Armenians, or Tutsi. My point is to show that it was not only murderers to have experienced different biographical trajectories that made them genocidal, but also to demonstrate that the reasons why people would often support mass extermination could be as banal as the emergence of the opportunities to seize the "cleansed" economic niches and thereby to improve the living standards of their own families. Furthermore, if we choose to remember that there were people who - functioning in the same conditions, though not under different circumstances (which, of course, would often be the case as well) - murdered people, and others who rescued the victims, we will avoid hasty generalizations. ${ }^{11}$

The complexity of disputes over the advantages and disadvantages of the comparative method exceeds the frames adopted in this article, as they often concern the essential questions of epistemology. Importantly, it is worth remembering that even the use of the inductive reasoning in this type of research is sometimes criticized, in which context the tension between the description of

9 T. van Leeuwen: "The Representation of Social Actors." In: C.R. Caldas-Coulthard, M. Coulthard (eds.): Texts and Practices. Readings in Critical Discourse Analysis. London-New York 1996, pp. 46-50.

${ }^{10}$ See: H. Welzer: Täter: Wie aus ganz normalen Menschen Massenmörder werden, with M. Christ. Frankfurt am Main 2005. See also: H. Welzer: "On Killing and Morality: How Normal People Become Mass Murderers.” In: O. Jensen, C. Szejnmann (eds.): Ordinary People as Mass Murderers. Perpetrators in Comparative Perspectives. London 2008. DOI: https://doi .org/10.1057/9780230583566_8.

${ }^{11}$ B. Campbell: "Contradictory Behavior During Genocides." Sociological Forum 2010, vol. 25 , no. 2, pp. 296-314. 
the facts and the development of the theory is often emphasized. ${ }^{12}$ However, in the practice of social sciences no "pure" induction, unsupported by general conceptions, exists. Inductive reasoning does not protect us against the consequences of the application of collectivist logic, because it also fosters the perception of individual actors - albeit guided by specific motives - as representatives of a given social category. The above notwithstanding, there is no doubt that building one's analysis upon the foundation of rich field research material compels the researcher to recognize the co-existence of a plethora of biographical trajectories, and of many paths of the mobilization for genocide.

\section{The Trajectories of the Symbolic Capital of "Genocide"}

The wide resonance of the notion of "genocide" resulted in the fact that the use of the term now implies the activation of the rather considerable resources of its symbolic capital. Let us recall that the term was coined by Rafał Lemkin. As early as in the interwar period (1918-1939), Lemkin proposed that "the crime of barbarity" and "the crime of vandalism" should both be incorporated in the codices of international criminal law as punishable offenses. On November 15th, 1944, while in exile in the United States, Lemkin published a monograph titled Axis Rule in Occupied Europe: Laws of Occupation, Analysis of Government, Proposals for Redress. In his book, he defined genocide as ${ }^{13}$

the destruction of a nation or of an ethnic group. [...] Generally speaking, genocide does not necessarily mean the immediate destruction of a nation, except when accomplished by mass killings of all members of a nation. It is intended rather to signify a coordinated plan of different actions aiming at the destruction of essential foundations of the life of national groups, with the aim of annihilating the groups themselves. The objectives of such a plan would be disintegration of the political and social institutions, of culture, language, national feelings, religion, and the economic existence of national groups, and the destruction of the personal security, liberty, health, dignity, and even the lives of the individuals belonging to such groups. Genocide is directed against the national group as an entity, and the actions involved are directed against individuals, not in their individual capacity, but as members of the national group. ${ }^{14}$

${ }^{12}$ C. Calhoun: "Explanation in Historical Sociology: Narrative, General Theory, and Historically Specific Theory." American Journal of Sociology 1998, vol. 104, no. 3, pp. 846-871.

${ }^{13}$ R. Lemkin: Axis Rule in Occupied Europe: Laws of Occupation, Analysis of Government, Proposals for Redress. Washington 1944, pp. 79-95.

${ }^{14}$ Ibidem, p. 79. 
Lemkin distinguished several "techniques of genocide in various fields"15 and discussed each of them in detail. Interestingly, while describing them, he referred to the situations of nations which - as is commonly believed - were not affected by the genocidal oppression (e.g. the Luxembourgers). He distinguished seven genocidal techniques. (1) Political (the destruction of self-governance, the disorganization of the political system, the replacement of the original toponyms and personal names with German names, the creation of the German People's List (Deutsche Volksliste, DVL), displacements, the organization of Nazi parties, etc.). (2) Social (the abolishment of local law and the dissolution of domestic courts, the extermination of the intelligentsia, etc.). (3) Cultural (the ban on the use of the local language and on the cultivation of tradition, destruction of the monuments of national legacy, looting of the objects representing national heritage, etc.). (4) Economic (the destruction of the foundations of the economic life of the group, the lowering of its standards of living, the confiscations of property, trade exclusions, etc.). (5) Biological (the implementation of depopulation policies, the lowering of the birthrate within the group, separating local women and men, encouraging extramarital procreation with the Germans, etc.). (6) Physical (racial discrimination in the sphere of nutrition, intentional fostering of poor living conditions, depriving groups of conditions warranting continued health, mass killing, etc.). (7) Religious (the diminution of the role of religion as a repository of national identity, plunder and destruction of church property, persecution of clergy, etc.). (8) Moral (the weakening of the group's moral sensitivities by encouraging alcohol abuse, addiction to pornography, gambling etc.). Importantly, in the context of his reflection on mass killings, in his book Lemkin mentioned three nations: the Poles, the Russians, and the Jews. ${ }^{16}$

It was only partially that Lemkin's multifaceted conception was accommodated in the international law. The Convention on the Prevention and Punishment of the Crime of Genocide was adopted by the General Assembly of the United Nations on December 9th, $1948 .{ }^{17}$ As a result of the hard bargain driven by the superpowers of the time, the definition of genocide was tailored specifically to meet the expectations of the major state capitals on both sides of the Iron Curtain. It is for this reason that the definition failed to include political groups as victims of genocide; likewise, among others, cultural genocide was excluded from its semantic field..$^{18}$ Furthermore, for years, the Convention had remained

15 Ibidem, pp. 82-90.

16 Ibidem, p. 88.

17 The Convention on the Prevention and Punishment of the Crime of Genocide. Adopted by the General Assembly of the United Nations on 9 December 1948. The Convention entered into force on January 12th, 1951. Poland ratified it on July 18th, 1950.

18 P.R. Bartrop, S. Totten: “The History of Genocide: An Overview.” In: S. Totten (ed.): Teaching about Genocide: Issues, Approaches, and Resources. Greenwich 2004, pp. 36-39. 
a dead-letter law, which becomes clear if we recall that even in Nuremberg no one was convicted of genocide; in fact, perpetrators of genocide were sentenced on account of three other charges: committing crimes against humanity, war crimes, and crimes against peace. And it was not until the 1990s that two ad hoc criminal tribunals were assembled: the International Criminal Tribunal for the former Yugoslavia (ICTY) and the International Criminal Tribunal for Rwanda.

One of the side effects of the trials of the war criminals, and more specifically, of the world-wide resonance of the verdicts that they heard, was the fact that the concept of genocide itself gained significance in international discourse. It is important because one must remember that before the trials the popularity of its use varied. Even those seeking compensation would use the word "genocide" sparingly, preferring to concentrate upon specific types of individual damage. ${ }^{19}$ In addition, the concept competed with other prominent terms, such as the Holocaust (which term started resonating far and wide in the global discourse first as a result of the popular interest in the trial of Adolf Eichmann (1960-1962), and later - after the four-episode television series titled Holocaust was aired in America in 1978). Undoubtedly, for many, the word "genocide" was just another name for the Holocaust, and hence, in many milieus, the association of the term "genocide" with the Shoah gradually became the primary association. Despite that, it was the war atrocities sensu largo, and not solely the extermination of the Jews, that gave rise to genocide studies. ${ }^{20}$ Although tracing the history of these concepts could be an interesting subject to address, at this point it is important to observe that along with the growing awareness of the crimes perpetrated in the course of the Second World War and with the increase in the amount of the cultural production thereto related, also the symbolic capital of the concept of "genocide" increased in value. ${ }^{21}$

As a result, subsequent groups would appropriate these terms to reinforce their own message and to gain wider support for their demands. Above all, it is important to observe the groups in question consisted of individuals who had fallen victim to this type of a crime, but their uniqueness as communities failed to win international recognition. For instance, striving to make their audiences aware that during the Second World War they, too, were victims of genocide, the Roma would invoke the concept of "the Roma Holocaust." To this day, even though the proper names for the mass extermination of the Roma people - such

19 A. Woolford, S. Wolejszo: "Collecting on Moral Debts: Reparations for the Holocaust and Pořajmos." Law \& Society Review 2006, vol. 40, no. 4, p. 882.

${ }^{20}$ A.D. Moses: "Revisiting a Founding Assumption of Genocide Studies." Genocide Studies and Prevention 2011, vol. 6, no. 3, pp. 287-300.

${ }^{21}$ Cf. J.C. Alexander: The Meanings of Social Life. A Cultural Sociology. Oxford 2005. In preparation for this article I referenced the Polish edition of the monograph: J.C. Alexander: Znaczenia społeczne. Studia z socjologii kulturowej. Trans. S. Burdziej, J. GĄDECKI. Kraków 2010, pp. 223-303. 
as Porajmos (devouring) or Samudaripen (genocide) - do exist in the Romani language, many authors still choose to use the term "Roma Holocaust" in their writings. ${ }^{22}$ In this context, it should be noted that the very question of why the Roma experienced such problems with disseminating their interpretation of history deserves more detailed attention. When we compare the respective modi operandi of the Jewish and the Roma organizations after the war, it becomes evident that the former created an efficient international network connecting diasporas, simultaneously relying upon the generally accepted national structures, to thereby maximize the use of available resources, and to dynamically mobilize supporters. ${ }^{23}$

To provide one more example, it is worth referring to the practices of the Herero people, who took legal action to enforce the German recognition of the genocide perpetrated in the German South-West Africa (now Namibia) in the years 1904-1905. Their actions are, admittedly, a source of justified controversy, because it is Namibia, not the Herero people, that is a party to international agreements, because apart from the Herero people it is also the members of the Nama group who fell victims to genocide, and finally because the class action complaint against the Federal Republic of Germany was filed in the United States, which allows Germany, a sovereign power, to claim immunity on the basis of the sovereign equality of the States. ${ }^{24}$

Similarly, indigenous peoples, descendants of the colonized, exterminated, and discriminated First Nations of countries such as the USA, Canada, or Australia, capitalized on the symbolic power of the term "genocide." As Dorota Głowacka emphasizes, "Indigenous activists began to use Holocaust metaphors to undermine the dominant narrative of the pioneer settlement of North America, and demand the recognition of colonial crimes as genocide." 25 Emphasis was put on a wide variety of the forms of extermination, exploitation, and discrimination, but it was the issues of the cultural genocide, of which Lemkin wrote as early as in 1944, that came to the fore. Particularly distressing was the issue of the residential schools for Indigenous children, which were an institutionalized form of the deprivation of the native population of its ethnic identity. In all cases cited, children were victims not only of strenuous assimilation practices (including the prohibition on the use of their native language, a ban on the cultivation of ethnic rites, and a ban on the contact with families),

22 Cf. J. Talewicz-Kwiatkowska: “Holokaust Romów. Czy rzeczywiście zapomniany?" Nigdy Więcej 2016, no. 22, nigdywiecej.org/pdf/pismo/22/holocaust_romow.pdf [accessed: 20.09.2020].

23 A. Woolford, S. Wolejszo: “Collecting on Moral Debts...," pp. 871-901.

${ }^{24}$ R. Anderson: "Redressing Colonial Genocide under International Law: The Hereros' Cause of Action against Germany." California Law Review 2005, vol. 93, no. 4, pp. 1155-1189.

25 D. GŁowackA: Po tamtej stronie: świadectwo, afekt, wyobraźnia. Warszawa 2016, p. 249. Translated by Paweł Jędrzejko. 
but also of eugenic experiments and of violence, including sexual abuse. According to some estimates, in 1910-1970, between 10\% and 30\% of Aboriginal children were taken away from their parents to be sent away to missions, special centers, or foster families. ${ }^{26}$ In April 1997, the Australian parliament announced an investigation into the forced removal of children from Aboriginal families and from the Torres Strait Islander communities. ${ }^{27}$ Yet, it was not until February 13th, 2008, that the Australian prime minister was finally ready to issue a formal apology to the Aborigines. Similar crimes against children were perpetrated in other parts of the world, including Canada. ${ }^{28}$ In its 2015 report, the Truth and Reconciliation Commission overtly stated that cultural genocide in Canada did, in fact, take place. ${ }^{29}$

Of course, such endeavors are criticized as pointlessly contributing to the "Suffering Olympics." But Charles Mills argues that this is one of the few ways in which the knowledge of Indigenous peoples may become widely accepted. And yet, victims are forced to negotiate their demands for historical and social justice using the language of the "white cognitive system." ${ }^{30}$ Therefore, it is not the goal of such actions to build a solid foundation for actual comparative studies: its driving force is the illocutionary purpose of the genocide narratives, which is the global recognition of the crimes perpetrated by the colonialist.

Within these narratives, we were able to encounter a wide spectrum of discursive strategies, including those based on the comparison of the described crimes with the genocide of the Jews. Such comparisons did not always meet the requirements of academic reliability. But that was not their purpose either. This does not mean, however, that in such a context there is no room for legitimate comparative studies. The comparison of genocides (recognized as such by researchers) with different forms of colonial violence may lead to very interesting conclusions, even if we should ultimately resolve that acts of violence against the Indigenous populations of the colonized territories do not fall under the category of genocide.

${ }^{26}$ C. Hooper: Tall Man: The Death of Doomadgee. New York 2009. In preparation for this article, I used the Polish edition of the text: C. Hooper: Wysoki. Śmierć Camerona Doomadgee. Trans. A. Nowakowska. Wołowiec 2010, p. 66.

${ }^{27}$ Bringing Them Home. National Inquiry into the Separation of Aboriginal and Torres Strait Islander Children from Their Families. Human Rights and Equal Opportunity Commission. Sydney 1997.

${ }^{28}$ Cf. D.B. MacDonald, G. Hudson: "The Genocide Question and Indian Residential Schools in Canada." Canadian Journal of Political Science / Revue canadienne de science politique 2012, vol. 45, no. 2, pp. 427-449.

${ }^{29}$ Honouring the Truth, Reconciling for the Future. Summary of the Final Report of the Truth and Reconciliation Commission of Canada. The Truth and Reconciliation Commission of Canada 2015, p. 1.

${ }^{30}$ D. GŁowacka: Po tamtej stronie..., p. 280. 
Notwithstanding the foregoing reflection, as always, one should beware lest collectivist logic lead one astray. Not all Indigenous people inhabiting the colonized territories were victims of genocide - or victims at all. A significant proportion of Aboriginal population of the New World and Australia died of diseases that were endemic in Europe: mainly smallpox, measles, influenza, and typhus. ${ }^{31}$ Also, the intensity of tribal warfare increased under the influence of the presence of Europeans, frequently reaching a genocidal scale, as was the case with the Jívaro people (the famous head hunters), the Iroquois, the Mãori, or the Dani. ${ }^{32}$ Native people would oftentimes serve in the colonial armies, regularly participating in acts of violence leveled against their own kinsmen. The Aboriginal inhabitants of the colonized territories were as diverse as the colonizers, although, of course, the racial difference generated a fundamental asymmetry between the Europeans and the Natives both in terms of the attainability of the positions of power and in terms of their life chances.

The strategies of animal rights defenders, who would often compare mass breading and slaughter of animals to the Holocaust, proved more controversial. Since these issues have already been addressed in Narrations of the Shoah, ${ }^{33}$ I feel relieved of my obligation to make a broader introduction. Suffice it to say that such a comparison first surfaced immediately after the war in the works of Theodor W. Adorno and, originally, it did not arouse as much controversy as it does today. ${ }^{34}$

At this point, it seems productive to refer to Charles Patterson's influential book Eternal Treblinka. ${ }^{35}$ Although the author sets ambitious goals for himself, it is not a work that meets the criteria of a scientific monograph. Rather, it is a manifesto of an animal rights' protector. It is relevant, however, that the book frequently references Helmut Kaplan, who explicitly wrote about "the animal holocaust," and that Patterson himself builds his argument upon the similarities between the treatment of the animals in the modern economy and the treatment of the Jews by the Germans. ${ }^{36} \mathrm{He}$ also puts forward a much stronger thesis - that the mode of dealing with farm animals paved the way for the mass extermination of people by the genocide perpetrators ("the road to Auschwitz begins at the slaughterhouse" ${ }^{\text {") }}$ ). Importantly, as a rule, books of this type are not intended to humiliate the Jewish

${ }^{31}$ J. Diamond: Guns, Germs, and Steel: The Fates of Human Societies. New York-London 1999.

32 J.P. BLICK: "Genocidal Warfare in Tribal Societies as a Result of European-Induced Culture Conflict." Man (New Series) 1988, vol. 23, no. 4, pp. 654-670.

${ }^{33}$ Cf. M. Loba: "Zagłada, ofiara i zwierzęta w myśli Elisabeth de Fontenay." Narracje o Zagładzie 2017, no. 3, pp. 42-50.

${ }^{34}$ T.W. Adorno: Minima Moralia. Reflections from Damaged Life. Trans. E.F.N. Jepнсотт. London 1999, pp. 105, 115.

${ }^{35}$ C. Patterson: Eternal Treblinka: Our Treatment of Animals and the Holocaust. New York 2002.

${ }^{36}$ Cf. Ibidem, pp. 101, 109-135, et passim.

${ }^{37}$ Ibidem, p. 53. 
victims of the concentration camps; they are not manifestations of any anti-Semitic strategy at play. Rather, using the symbolic capital of the concept of the Holocaust, such texts attempt at strengthening the message of the defenders of animal rights, who strive to make the general public aware of the scale of atrocities perpetrated daily in laboratories, industrial breeding farms, and slaughterhouses.

Again, academic comparative studies are feasible in this case. It is possible not only to compare the practices of mass slaughtering of the animals with the extermination of people at the time of the genocide, but also to seek answers to the question concerning the extent to which the ever-present practice of mass breeding and slaughtering of animals could have facilitated the dehumanization of victims, for instance - by contributing to the promulgation of particular practices, habituses, or, at least, social concepts, which may have proven transferable onto other spheres of life (and which, for example, Zygmunt Bauman successfully demonstrated invoking the metaphor of the "Gardening State"). ${ }^{38}$

Comparing people and animals as suffering beings is obviously legitimate and ethically justified, ${ }^{39}$ but it cannot lead to equating people and animals as subjects, which is not a rare practice among the defenders of animal rights. It is not only about the language problems that become manifest when phrases such as "animal genocide" or "dehumanization of animals" enter the public space: much more importantly, it is about the fact that human agency ${ }^{40}$ renders people and animals radically different as actors of the historical drama.

Naturally, in the case of comparisons juxtaposing humans and animals (and I do not refer to the strategies of ethology here), the boundaries of comparative studies are far clearer than in the cases analyzed above. It would hardly be possible to consider the mass extermination of pathogens or insects as a practice that could be conceived as comparable - even remotely - to the mass extermination of people (even though, in the long run, the annihilation of insects or pathogens may have such consequences). But, without a doubt, the wandering of concepts and metaphors related thereto is easy to observe. ${ }^{41}$ Despite resonant generalizations, it is the mammals (especially those close to us genetically) whom we are ready to grant the status of subjects. It is thereby that we are prone to perceive acts of cruelty leveled at them as conditioned by the same social mechanisms that manifest themselves in relations among humans. Interestingly, when describing animals, we apply collectivist logic without hesitation: we have no dilemma. Differentiating between animals representing the same species - animals falling prey to human cruelty - on the basis of the quality of their character, inherent nature, or intelligence is almost unheard of.

${ }^{38}$ Z. Bauman: Modernity and the Holocaust. Ithaca, N.Y. 1989.

39 P. Singer: Animal Liberation. New York 2002.

${ }^{40}$ The concept is understood in accordance with the proposition by M. ArCHER: Culture and Agency. The Place of Culture in Social Theory. Cambridge 1996.

${ }^{41}$ M. ŻóŁкоś: “Insektosemityzm.” Narracje o Zagładzie 2017, no. 3, pp. 51-65. 


\section{Moral Communities and Genocides}

Genocide studies are involved in various public discourses related to the reproduction of the nation as a moral community. The stance adopted by genocide researchers is commented, criticized, and used in current politics. Among others, it is owing to Pierre Bourdieu that we realize that the world of scholarship and science is not a world in which scientists and scholars work together as peers in search of truth, ready to quickly abandon falsified theories. The academic field is a battlefield: a space of struggle for the highest available position and for the power that comes with it, while one's scientific or scholarly capital turns out to be the derivative of capital resources, which are at one's disposal owing to the "privilege" of having been born into a family enjoying a high enough position in the class structure. The connections between scientific/scholarly and nationalist discourses are therefore numerous and strong, which should hardly surprise anyone in Poland, where I live and work. However, this is not an affliction unique to any given country: it is a peculiar characteristic of academic work in nation-states in general. It is enough to recall how closely the fates of cultural anthropologists were tied to the processes of the colonization of new territories.

Some aspects of academic work attract popular attention more than others: above all, it is the aspect of the fallout of the official announcement of our findings. Public attention will certainly be stirred when we qualify a given crime as genocide, or - conversely - when we state that a given crime cannot be qualified as genocide. This, of course, strictly depends on the principles we follow while compiling the catalog of genocides to be compared, but, beyond doubt, either of these statements will arouse considerable emotions when they concern events of particular importance to a given national community.

In Poland, for instance, such was the situation when academics announced that the so-called Volhynia slaughter and the Katyń massacre did not qualify as genocides. In the first case, the bloody mass murders perpetrated primarily by the Ukrainian Insurgent Army in the south-eastern territories of the Second Polish Republic - mostly in the regions of Volhynia and Eastern Galicia - in the years 1943-1944 loom large in the highly politicized historical debate. In the second case, to the Poles, Katyn is a powerful symbol of Soviet crimes against the officers of the Polish Army and State Police (not all of whom were ethnic Poles), who were massacred as prisoners of war, and whose remains are now buried at the cemeteries in Katyń, Mednoye, and Kharkiv.

Outraged at the crimes perpetrated against their own national (ethnic) group, the Poles seem to be equally outraged by the claim that the Polish people contributed to the genocide of the Jews. This issue is usually raised in three principal contexts. The first of the three is the context of the pogroms that took place in June and July 1941, after the outbreak of the war between the Third 
Reich and the USSR (the most terrible of the crimes were perpetrated in the moments of the escalation of the pogroms, i.e. on July 7th in Radziłów and on July 10th in Jedwabne). The second context is that of the participation of the Polish uniformed services (including the "Blue Police" massacres of the Jewish population. The third context is that of the involvement of the Poles in the "Jew Hunts" (Judenjagd). These cases, arguably, arouse the most heated emotions, but the repertoire of accusations leveled at academics does not end there. For example, scholars are often criticized for having qualified too few of the crimes committed during the communist rule as "communist genocides." ${ }^{33}$ And although many other instances of such ongoing debates world-wide could be quoted here, it may be argued that the most systematic and farthest-reaching of the negationist stances is that officially adopted by Turkey, which country's formal position is to defend the claim that Armenians never fell victim to genocide. $^{44}$

These examples demonstrate - first - that the interest of the public opinion in academic findings of this type is an exponent of the high symbolic capital of the concept of "genocide." The claim that the Poles are guilty of genocide is publicly perceived as harsh criticism of the whole national (ethnic) community, while, at the same time, the refusal to call the crimes perpetrated against the Poles "genocide" is treated as tantamount to the diminishment of the national heroism in the face of the hecatomb. In this situation, universal discursive strategies are at play: strategies aiming at silencing events negatively impacting the communal self-esteem and at the protection of the positive identity of one's own group which phenomenon has been addressed, among others, by Aleida Assmann. ${ }^{45}$ In such cases, social reactions may assume the form of a sharp attack leveled at the scholar daring to publish findings that do not conform to the communal expectations.

Secondly, juxtaposing crimes in which members of one's own group performed the role of either victims or perpetrators within the frame of academic

${ }^{42}$ The official name of the Blue Police was the Polnische Polizei im Generalgouvernement (the Polish Police of the General Government). It was a police force based on ethnic Poles recruited from the ranks of the pre-war State Police, and led by the German supervising officers.

${ }^{43}$ In communist countries, such as the USSR or China, a substantial number of people were annihilated, but in most cases researchers agree that the killings were not tantamount to genocide, but to other forms of violence leveled at social groups (e.g. collectivization terror). For more information, see: M. Mann: The Dark Side of Democracy. Explaining Ethnic Cleansing. Cambridge 2006, pp. 318-352.

${ }^{44}$ J. OlĘDzKa: "Relatywizacja ludobójstwa jako instrument stosunków geopolitycznych na przykładzie politycznego dyskursu o ludobójstwach Ormian i Czerkiesów." In: B. MACHULTelus, U. Markowska-Manista, L.M. Nijakowski (eds.): Krwawy cień genocydu. Cz. 2. Ludobójstwa - pamięć, dyskurs, edukacja. Warszawa 2017, pp. 129-153.

${ }^{45}$ A. Assmann: "Fünf Strategien der Verdrängung." In: Der lange Schatten der Vergangenheit Erinnerungskultur und Geschichtspolitik. München 2006, pp. 169-182. 
comparative studies may lead to the formulation of theses that could question the fundamentals of positive self-stereotyping within the group itself. Discussing this issue, however, I leave aside extreme positions, whose advocates claim that the very attempt at drawing comparisons of this kind violates the honor of "our victims" (which discourse is often resorted to by Jewish intellectuals, considering the Shoah as an "exceptional" case of genocide).

In such a situation, comparatist logic, which is an integral and inalienable part of any nationalist discourse ${ }^{46}$ is responsible for the fact that scholarly theses concerning a particular group of individuals are immediately generalized to refer to the entire nation, whose dignity or honor must be defended. For instance, when referring to Germans, a researcher has in mind a specific collective actor, such as the SS, the Wehrmacht, the NSDAP, the civilians of a given city, or others. The public opinion, however, perceives the scholar's claims as claims concerning the whole nation, which is thereby construed as a nation of the perpetrators of unspeakable crimes and is collectively to blame. This is where the destructive work of collectivist logic becomes most clearly manifest: it is such logic that perpetuates ethnic or national prejudice, leading to the proliferation of hate speech and, by extension, to frequently brutal attacks leveled at academics. Of course, scientists and scholars should be aware that their messages must be formulated as precisely and as skillfully as possible, and - especially in cases like those discussed - that sharing one's point of view with popular audiences by means of outreach talks or well-structured articles dedicated specifically to non-academic audiences might help disperse any doubts that the public opinion might have in the first place. But even the best education will not make the public discourse academic. This is related to the structural difference setting the narratives of both types apart, but also to the dissimilarity of strategies that each of these discourses employs, and to the difference in positions occupied by the chief speakers. Needless to say, whenever politicians engage in such a dispute with the view to boosting their political capital, ritual chaos $^{47}$ becomes the dominant mode of public debate.

The state politics of memory is therefore a space of constant temptation for scientists and scholars specializing in mass crimes. Museums, foundations, and other institutions indeed require their knowledge, but when it is offered, it is usually contextualized in the binary frame of collective guilt and collective merit. This, for instance, is manifest in the case of a strong discourse whose macro-level, global illocutionary function is to assert that the Poles did not collaborate with the German invaders during the Second World War. We know well

${ }^{46}$ R. Wodak, R. De Cillia, M. Reisigl, K. Liebhart: The Discursive Construction of National Identity. Trans. A. Hirsch, R. Mitten. Edinburgh 2003.

${ }^{47}$ M. Czyżewski: “W stronę teorii dyskursu publicznego.” In: M. Czyżewski, S. Kowalski, A. Piotrowski (eds.): Rytualny chaos. Studium dyskursu publicznego. Warszawa 2010, pp. 49-70, 92-117. 
that some citizens of the Second Polish Republic of different ethnic backgrounds and declaring various national identities did actively collaborate with the Nazi regime. How else to assess the functioning of the Polish Police of the General Government? How else to interpret the role of the Poles recruited for the German auxiliary police units? ${ }^{48}$ This, however, does not mean that all the Poles collaborated with the Nazis, driven by morally reprehensible motives. Some did it under the economic pressure of the occupation, others acted on the orders of the underground resistance movement, while still others were not tempted - or even heroically refused - to collaborate with the enemy. Such distinctions, however, are at odds with the hegemonic discourse.

\section{Recapitulation}

Any two (or more) objects may be compared for scientific or scholarly purposes. In the academic discourse, comparisons are not tools serving the purpose of diminishing the importance of any of its objects, slandering anyone, or mockery. Of course, comparative studies must be based on meaningful research questions and well-formulated hypotheses. In the case of some comparisons, however, one may predict that their results will prove to be of little use to scholarship or science. For example, a comparative analysis of different types of concentration camps and Jewish ghettos during the Second World War may indeed reveal to us a variety of universal forms of violence, supervision, and manipulation, which allowed the Nazis to succeed in concentrating their victims, exploiting them, and finally exterminating them. However, if we compare the Jewish ghettos of the Second World War with the African American "ghettos" in various metropolitan areas in the US, the conclusions may not be as interesting. For a scientist or a scholar planning to employ the laborious method of historical comparative studies in his or her research, the choice of the subject of comparison is of strategic importance.

Numerous examples can be provided to demonstrate that the application of historical comparative analysis to genocide studies may lead to interesting findings. For example, Robert F. Melson compares the Holocaust with the Armenian Genocide to demonstrate that, respectively, the Nazi revolution and the Young Turk revolution - both further catalyzed by the ensuing wars - generated conditions conducive to genocide. ${ }^{49}$ Michael Mann's comparative analysis leads

${ }^{48}$ M. Wenklar: "Polacy w niemieckiej policji pomocniczej. Schutzmannschaftsbataillon 202 w świetle zeznań jego członków.” Acta Universitatis Wratislaviensis 2012, no. 3505, Studia nad Autorytaryzmem i Totalitaryzmem 34, no. 4, Wrocław 2012, pp. 35-50.

49 R.F. Melson: Revolution and Genocide. On the Origins of the Armenian Genocide and the Holocaust. Chicago-London 1992. 
him to the conclusion that the probability of the outbreaks of murderous ethnic cleansings has proven higher in areas in which settler democracies came into existence (not only de iure, but also de facto). This is how the scholar explained the mechanisms underlying the extermination of the Aboriginal nations in the US and in Australia and the birth of the Mestizo society in the former Spanish colonies. ${ }^{50}$

The above notwithstanding, comparative historical studies come at a cost. When comparing social projects of such magnitude as genocides, one has no other choice but to simplify the cases under analysis. And, if we are aware of how we reduce the complexity of the analyzed world and render this awareness visible in the argumentative structure of our texts, we may arrive at interesting results. The problem is that collectivist logic has a way of creeping into academic discourses, leading to the homogenization and substantialization of the categories of perpetrators, victims, and witnesses, despite the fact that the trajectory of each actor of the genocide, irrespective of their role in it, is complex: even individual choices to commit crimes are made in specific situations and are conditioned by a plethora of diverse factors.

The power of the symbolic capital attributed to the concept of "genocide" was the reason why the term began to be used in reference to other mass crimes, or even for the purpose of the defense of animal rights. As a rule, in such cases we deal with non-academic discourses, usually aiming at the recognition of the ordeal of the described group, or offering a persuasive message intended to encourage the recipient to support the demands of the green movements. Yet, even in these contexts comparative approaches are feasible, although, admittedly, one may doubt if such analyses would produce conclusions of value. Whatever the context, however, it is of paramount importance to avoid the pitfalls of collectivist logic, which - especially in such cases - are particularly easy to overlook.

Finally, it is the social environment in which the scholars and scientists work that poses the most serious threat that they will succumb to the temptations of the nationalist discourses and the memory politics monopolized by the state. When the public opinion demands of the academics to legitimize hegemonic discourses respecting collective guilt or collective merit with their scientific or scholarly capital of knowledge, it is a true challenge to demonstrate one's integrity by maintaining methodological rigor in showing the multitude of stances adopted by a multitude of individuals in the times of genocides.

\footnotetext{
${ }^{50}$ M. Mann: The Dark Side of Democracy...
} 


\section{Bibliography}

Adorno T.W.: Minima Moralia. Reflections from Damaged Life. Trans. E.F.N. Jернсотт. London 1999.

Alexander J.C.: The Meanings of Social Life. A Cultural Sociology. Oxford 2005.

Alexander J.C.: Znaczenia społeczne. Studia z socjologii kulturowej. Trans. S. Burdziej,

J. GĄDECKI. Kraków 2010.

Anderson R.: "Redressing Colonial Genocide under International Law: The Hereros' Cause of Action against Germany." California Law Review 2005, vol. 93, no. 4, pp. 1155-1189.

Archer M.: Culture and Agency. The Place of Culture in Social Theory. Cambridge 1996. Assmann A.: "Fünf Strategien der Verdrängung." In: Der lange Schatten der Vergangenheit Erinnerungskultur und Geschichtspolitik. München 2006.

Bartrop P.R., Totten S.: “The History of Genocide: An Overview.” In: S. Totten (ed.): Teaching about Genocide: Issues, Approaches, and Resources. Greenwich 2004.

BAUER Y.: Rethinking the Holocaust. New Haven 2002.

BAUMAN Z.: Modernity and the Holocaust. Ithaca, N.Y. 1989.

BLICK J.P.: "Genocidal Warfare in Tribal Societies as a Result of European-Induced Culture Conflict.” Man (New Series) 1988, vol. 23, no. 4, pp. 654-670.

Bringing Them Home. National Inquiry into the Separation of Aboriginal and Torres Strait Islander Children from Their Families. Human Rights and Equal Opportunity Commission. Sydney 1997.

Calhoun C.: "Explanation in Historical Sociology: Narrative, General Theory, and Historically Specific Theory.” American Journal of Sociology 1998, vol. 104, no. 3, pp. 846-871.

Campbell B.: "Contradictory Behavior During Genocides." Sociological Forum 2010, vol. 25, no. 2, pp. 296-314.

Czyżewski M.: "W stronę teorii dyskursu publicznego.” In: M. CzyżEwski, S. Kowalski, A. Piотrowski (eds.): Rytualny chaos. Studium dyskursu publicznego. Warszawa 2010.

Diamond J.: Guns, Germs, and Steel: The Fates of Human Societies. New York-London 1999.

GŁowacka D.: Po tamtej stronie: świadectwo, afekt, wyobraźnia. Warszawa 2016.

Harff B., Gurr T.R.: "Systematic Early Earning of Humanitarian Emergencies." Journal of Peace Research 1998, vol. 35, no. 5, pp. 551-579.

Harff B.: "No Lessons Learned from the Holocaust? Assessing Risks of Genocide and Political Mass Murder since 1955.” American Political Science Review 2003, vol. 97, no. 1 , pp. $57-73$.

Honouring the Truth, Reconciling for the Future. Summary of the Final Report of the Truth and Reconciliation Commission of Canada. The Truth and Reconciliation Commission of Canada 2015.

Hooper C.: Tall Man: The Death of Doomadgee. New York 2009.

Hooper C.: Wysoki. Śmierć Camerona Doomadgee. Trans. A. Nowakowska. Wołowiec 2010. 
LEMkin R.: Axis Rule in Occupied Europe: Laws of Occupation, Analysis of Government, Proposals for Redress. Washington 1944.

Lова M.: “Zagłada, ofiara i zwierzęta w myśli Elisabeth de Fontenay.” Narracje o Zagładzie 2017, no. 3, pp. 42-50.

Mann M.: The Dark Side of Democracy. Explaining Ethnic Cleansing. Cambridge 2006.

MacDonald D.B.: Balkan Holocausts? Serbian and Croatian Victim Centred Propaganda and the War in Yugoslavia. Manchester 2002.

MacDonald D.B., Hudson G.: "The Genocide Question and Indian Residential Schools in Canada." Canadian Journal of Political Science / Revue canadienne de science politique 2012, vol. 45, no. 2, pp. 427-449.

McDoom O.S.: "Who Killed in Rwanda's Genocide? Micro-space, Social Influence and Individual Participation in Intergroup Violence." Journal of Peace Research 2013, vol. 50, no. 4, pp. 453-467.

Melson R.F.: Revolution and Genocide. On the Origins of the Armenian Genocide and the Holocaust. Chicago-London 1992.

Moses A.D.: "Revisiting a Founding Assumption of Genocide Studies." Genocide Studies and Prevention 2011, vol. 6, no. 3, pp. 287-300.

Nijakowski L.M.: Rozkosz zemsty. Socjologia historyczna mobilizacji ludobójczej. Warszawa 2013.

OlęDzKA J.: "Relatywizacja ludobójstwa jako instrument stosunków geopolitycznych na przykładzie politycznego dyskursu o ludobójstwach Ormian i Czerkiesów." In: B. Machul-Telus, U. Markowska-Manista, L.M. Nijakowski (eds.): Krwawy cień genocydu. Część 2. Ludobójstwa - pamięć, dyskurs, edukacja. Warszawa 2017, pp. 129-153.

Ostrowska J.: Przemilczane. Seksualna praca przymusowa w czasie II wojny światowej. Warszawa 2018.

Patterson Ch.: Eternal Treblinka: Our Treatment of Animals and the Holocaust. New York 2002.

Singer P.: Animal Liberation. New York 2002.

Sкосроl T.: Social Revolutions in the Modern World. Cambridge 1994.

SPIVAK G.Ch.: Death of a Discipline. New York 2003.

Talewicz-Kwiatkowska J.: “Holokaust Romów. Czy rzeczywiście zapomniany?” Nigdy Więcej 2016, no. 22, nigdywiecej.org/pdf/pismo/22/holocaust_romow.pdf [accessed: 20.09.2020].

Van Leeuwen T.: “The Representation of Social Actors.” In: C.R. Caldas-Coulthard, M. Coulthard (eds.): Texts and Practices. Readings in Critical Discourse Analysis. London-New York 1996.

Welzer H.: "On Killing and Morality: How Normal People Become Mass Murderers." In: O. Jensen, C. Szejnmann (eds.): Ordinary People as Mass Murderers. Perpetrators in Comparative Perspectives. London 2008.

Welzer H.: Täter: Wie aus ganz normalen Menschen Massenmörder werden, with M. Christ. Frankfurt am Main 2005.

Wenklar M.: "Polacy w niemieckiej policji pomocniczej. Schutzmannschaftsbataillon 202 w świetle zeznań jego członków.” Acta Universitatis Wratislaviensis 2012, no. 3505, Studia nad Autorytaryzmem i Totalitaryzmem 34, no. 4, Wrocław 2012, pp. 35-50. 
Wodak R., Cillia R. De, Reisigl M., Liebhart K.: The Discursive Construction of National Identity. Trans. A. Hirsch, R. Mitten. Edinburgh 2003.

Woolford A., Wolejszo S.: "Collecting on Moral Debts: Reparations for the Holocaust and Pořajmos." Law \& Society Review 2006, vol. 40, no. 4, pp. 871-901.

ŻóŁkoś M.: “Insektosemityzm.” Narracje o Zagładzie 2017, no. 3, pp. 51-65.

Lech M. Nijakowski

Logika kolektywistyczna w komparatystyce ludobójstw i walkach o pamięć

AвsтrAкт: W artykule przedstawiono działanie logiki kolektywistycznej na trzech obszarach: (1) w historycznej komparatystyce ludobójstw - podstawowej metodzie genocide studies; (2) w działaniach organizacji ofiar i ocalonych oraz obrońców praw zwierząt; (3) w dyskursach nacjonalistycznych i polityce pamięci. Logika kolektywistyczna to zbiór operacji, które podmiotem historii czynią zbiorowości ludzkie, postrzegane jako połączone ważnymi więziami społecznymi i interesami oraz odróżniające się kulturowo. W jej wyniku myślimy o zbiorowej winie i zasłudze. W artykule przedstawiono zalety i wady komparatystyki historycznej jako metody naukowej genocide studies. Następnie przeanalizowano wykorzystanie kapitału symbolicznego związanego z terminem „ludobójstwo" w porównywaniu innych zbrodni oraz gospodarczego wykorzystania zwierząt z ludobójstwami. Na koniec opisano związek państwowej polityki pamięci i dyskursów nacjonalistycznych z działalnością akademicką badaczy ludobójstw.

SŁOWA KLUCZE: komparatystyka historyczna, ludobójstwa, genocide studies, polityka pamięci

LECH M. NiJAKOWSKI - doktor habilitowany nauk społecznych, profesor uczelni, kierownik Zakładu Socjologii Ogólnej w Instytucie Socjologii Uniwersytetu Warszawskiego. Jego zainteresowania badawcze koncentrują się na: studiach nad ludobójstwem, socjologii etniczności, socjologii konfliktu, socjologii historycznej, studiach nad pamięcią zbiorową, analizie dyskursu, współczesnych teoriach socjologicznych. Opublikował sześć samodzielnych monografii naukowych, jest współautorem kolejnych trzech, redaktor lub współredaktor szesnastu tomów zbiorowych.

LeCH M. Nijakowski, associate professor of social sciences at the Institute of Sociology of the University of Warsaw. His research focuses on genocide studies, sociology of ethnicity, conflict sociology, historical sociology, studies on collective memory, discourse analysis, and contemporary sociological theories. He has authored six academic monographs and is a co-author of three more. To date, he has edited or co-edited sixteen multi-author monographs. 